\title{
Penggunaan Kembali Limbah Cair dari Sintesis Zeolit Y sebagai Sumber Silika untuk Sintesis Zeolit Y secara Hidrotermal
}

\author{
Endang Sri Rahayu *, Desi Bentang, Ghina Fauziyyah \\ Jurusan Teknik Kimia Politeknik Negeri Bandung \\ *e-mail: endang.srirahayu@ polban.ic.id
}

\begin{abstract}
Abstrak. Penelitian ini dilakukan untuk mempelajari kemungkinan limbah cair atau mother liquor dari sintesis zeolit $Y$ yang masih mengandung silika dapat digunakan kembali sebagai sumber silika untuk sintesis zeolit $Y$, dengan menambahkan bibit kristal dan alumina ke dalam limbah cair. Sintesis zeolite Y dilakukan secara hidrotermal pada temperatur $93^{\circ} \mathrm{C}$ dan $\mathrm{pH}$ sekitar 13. Rasio molar silika lalumina sekitar $10 \mathrm{~mol} / \mathrm{mol}$ di dalam starting material diperlukan untuk mendukung terbentuknya zeolit Y. Seberapa banyak turunan atau penggunaan kembali limbah cair sintesis zeolit $Y$ untuk sintesis zeolit $Y$, dikaji dalam penelitian ini. Hasil sintesis zeolit $Y$ diuji nilai rasio molar $\mathrm{SiO}_{2} / \mathrm{Al}_{2} \mathrm{O}_{3}$ dengan alat X-Ray Diffractometer (XRD), dan morfologinya dengan alat Scanning Electron Microscopy (SEM). Hasil sintesis zeolite Y menunjukkan hanya mother liquor turunan ke-1 saja yang layak digunakan kembali untuk sintesis zeolite $Y$ karena zeolite P terbentuk secara signifikan ketika digunakan mother liquor turunan ke-2. Penelitian ini juga mengamati bahwa pembentukan zeolite P terjadi ketika konsentrasi $\mathrm{SiO}_{2}$ dalam starting material adalah rendah. Konsentrasi $\mathrm{SiO}_{2}$ yang rendah pada mother liquor turunan ke-1 juga diduga berkontribusi terhadap penurunan rasio $\mathrm{SiO}_{2} / \mathrm{Al}_{2} \mathrm{O}_{3}$ pada zeolit $Y$ hasil sintesis, yaitu $2.63 \mathrm{~mol} / \mathrm{mol}$, dari $3.74 \mathrm{~mol} / \mathrm{mol} \mathrm{ketika} \mathrm{menggunakan}$ parent starting material. Peningkatan rasio $\mathrm{SiO}_{2} / \mathrm{Al}_{2} \mathrm{O}_{3}$ zeolit $Y$ hasil sintesis dapat diupayakan, yang tampak lebih baik dilakukan melalui penaikan jumlah bibit kristal dari pada melalui penaikan waktu reaksi, untuk memperkecil terbentuknya zeolite $P$.
\end{abstract}

Kata kunci: limbah cair, sumber silika, sintesis, hidrotermal, zeolit Y.

Abstract. Reuse of Liquid Waste from Zeolite Y Synthesis as a Silica Source for Hydrothermal Synthesis of Y Zeolite. The objective of this study was to study the possibility of mother liquor of synthesis of zeolite Y which still contains high silica, can be reused as a source of silica for synthesis of zeolite $Y$, by adding seeds and alumina. The synthesis of zeolite $Y$ was done hydrothermally at temperature of $93^{\circ} \mathrm{C}$ and at a pH of about 13. The mole ratio of silica / alumina in the starting material at about of $10 \mathrm{~mol} / \mathrm{mol}$ were needed to achieve an adequate process. How many derivatives or repetitions of the mother liquor can be reused for synthesis of zeolite $Y$, it will be examined in this study. The result of the synthesized zeolite $\mathrm{Y}$ was then characterized of the $\mathrm{SiO}_{2} / \mathrm{Al}_{2} \mathrm{O}_{3}$ molar ratio by X-Ray Diffraction (XRD) and the morphology by Scanning Electron Microscopy (SEM). The Results of the synthesis of zeolite Y shows that the only 1st mother liquor appropriate to be reused for synthesis of zeolite $Y$. The reduction of the $\mathrm{SiO}_{2} / \mathrm{Al}_{2} \mathrm{O}_{3}$ molar ratio of synthesized $Y$ zeolite from the $3.74 \mathrm{~mol} / \mathrm{mol}$ when using parent starting material become $2.63 \mathrm{~mol} / \mathrm{mol}$ when using mother liquor was observed The formation of zeolite $P$ was also obtained when synthesis zeolite $Y$ using mother liquor with a low concentration of $\mathrm{SiO}_{2}$. The $\mathrm{SiO}_{2} \mathrm{Al}_{2} \mathrm{O}_{3}$ molar ratio of the synthesized zeolite $Y$ can be raised by inceasing the quantity of seeds in the starting material rather than by increasing reaction time, to minimize the formation of zeolite $P$.

Keywords: mother liquor, silica source, synthesis, hydrothermal, zeolite $Y$.

Graphical Abstract

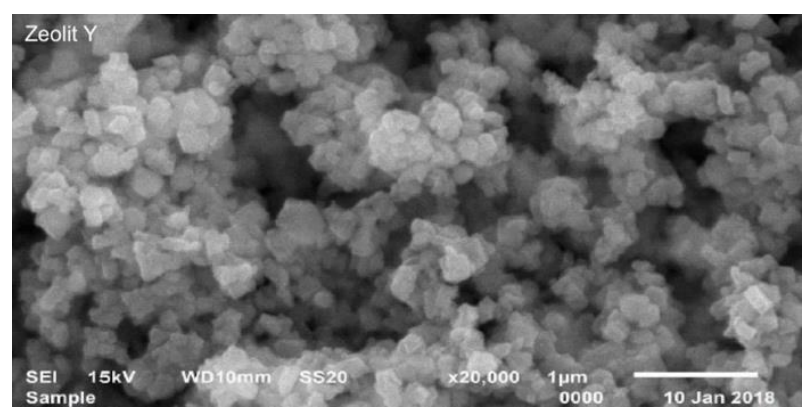

\section{Pendahuluan}

Sintesis zeolite $\mathrm{Y}$ memerlukan starting material yang memiliki kandungan $\mathrm{SiO}_{2}$ dan $\mathrm{Al}_{2} \mathrm{O}_{3}$ dalam rasio molar yang tertentu, yaitu sekitar $10 \mathrm{~mol} / \mathrm{mol}$. Selanjutnya, limbah cair atau mother liquor hasil sintesis zeolite $\mathrm{Y}$ yang masih mengandung $\mathrm{SiO}_{2}$ karena rasio 
$\mathrm{SiO}_{2} / \mathrm{Al}_{2} \mathrm{O}_{3}$ pada kerangka zeolit $\mathrm{Y}$ yang terbentuk jauh lebih rendah dari rasio yang berada dalam starting material. Silika sisa di dalam mother liquor ini diperkirakan dapat digunakan kembali sebagai sumber $\mathrm{SiO}_{2}$ untuk sintesis zeolite $\mathrm{Y}$. Secara umum, sintesis zeolite $\mathrm{Y}$ menggunakan bahan baku sintetik yang mengandung $\mathrm{SiO}_{2}$ dan $\mathrm{Al}_{2} \mathrm{O}_{3}$ yang harganya cukup mahal dan beberapa dekade ini bahan mineral mengandung $\mathrm{SiO}_{2}$ dan $\mathrm{Al}_{2} \mathrm{O}_{3}$ mulai diteliti untuk digunakan sebagai bahan baku pada sintesis zeolit Y. Di antara banyak jenis mineral, kaolin mengandung $\mathrm{SiO}_{2}$ dan $\mathrm{Al}_{2} \mathrm{O}_{3}$ dalam persentase tinggi. Kandungan $\mathrm{SiO}_{2}$ yang tinggi pada kaolin memiliki peluang untuk diolah menjadi zeolit $\mathrm{Y}$ seperti telah banyak dilakukan para peneliti terdahulu. Brown dan Woltermann (1980) menggunakan metode kalsinasi kaolin pada temperatur tinggi untuk menghasilkan $\mathrm{SiO}_{2}$ amorf sebagai nutrien pembentuk kristal zeolite $\mathrm{Y}$, menghasilkan kristalinitas 30-40\%-b dalam produk hasil sintesis. Li dkk. (2010), membuat zeolite $\mathrm{Y}$ dari kaolin aktif metakaolin hasil kalsinasi kaolin pada temperature rendah, sebagai sumber $\mathrm{SiO}_{2}$ dan $\mathrm{Al}_{2} \mathrm{O}_{3}$ untuk sintesis zeolite $\mathrm{Y}$, tetapi memerlukan waktu reaksi yang lebih panjang. Rahayu dkk. (2014) juga telah melakukan sintesis zeolite Y menggunakan kaolin aktif hasil kalsinasi pada temperatur tinggi $\left(1013^{\circ} \mathrm{C}\right)$, untuk menghasilkan $\mathrm{SiO}_{2}$ amorf sebagai sumber $\mathrm{SiO}_{2}$, menghasilkan produk dengan kristalinitas 55\%-b mengandung zeolite $\mathrm{Y}$ yang memiliki rasio molar $\mathrm{SiO}_{2} / \mathrm{Al}_{2} \mathrm{O}_{3}$ antara $4.1-5.5$ mol/mol. Murat dkk. (1992) membuat zeolite NaY dari kaolin, dan menyatakan bahwa untuk menghasilkan zeolit $\mathrm{Y}$ dengan rasio molar $\mathrm{SiO}_{2} / \mathrm{Al}_{2} \mathrm{O}_{3}>3,5 \mathrm{~mol} / \mathrm{mol}$ diperlukan starting material yang memiliki rasio molar $\mathrm{SiO}_{2} / \mathrm{Al}_{2} \mathrm{O}_{3}=7-10 \mathrm{~mol} / \mathrm{mol}$.

Akhir-akhir ini berlangsung perkembangan sintesis zeolite dari kaolin yang menggunakan metode pemisahan $\mathrm{SiO}_{2}$ dan $\mathrm{Al}_{2} \mathrm{O}_{3}$ aktif dari metakaolin melalui leaching, untuk menghasilkan rafinat yang kaya $\mathrm{SiO}_{2}$ dengan rasio molar $\mathrm{SiO}_{2} / \mathrm{Al}_{2} \mathrm{O}_{3}$ sesuai dengan yang dikehendaki., dengan pengaturan kondisi proses leaching. Adeoye dan Omoleye (2016) telah menggunakan rafinat kaya $\mathrm{SiO}_{2}$ dari leaching kaolin aktif hasil kalsinasi kaolin pada temperatur $850^{\circ} \mathrm{C}$ sebagai sumber $\mathrm{SiO}_{2}$ untuk sintesis zeolite $\mathrm{Y}$ dan menghasilkan zeolite $\mathrm{Y}$ dengan rasio $\mathrm{SiO}_{2} / \mathrm{Al}_{2} \mathrm{O}_{3}=3.46 \mathrm{~mol} / \mathrm{mol}$, setelah sintesis zeolite $\mathrm{Y}$ berlangsung dalam waktu yang panjang, Rahayu dkk. (2018) juga telah melakukan sintesis zeolite $Y$ menggunakan sumber $\mathrm{SiO}_{2}$ aktif dari rafinat hasil leaching metakaolin, dan menghasilkan zeolite $\mathrm{Y}$ yang memiliki rasio molar $\mathrm{SiO}_{2} / \mathrm{Al}_{2} \mathrm{O}_{3}$ antara 3.1-3.61 $\mathrm{mol} / \mathrm{mol}$, setelah reaksi berlangsung dalam waktu yang lebih pendek yaitu antara 8-18 jam.

Kembali pada kemungkinan penggunaan kembali mother liquor atau limbah cair dari sintesis zeolite $\mathrm{Y}$, makalah ini akan menyampaikan hasil-hasil sintesis zeolite $\mathrm{Y}$ dari beberapa jenis starting material yang menggunakan sumber $\mathrm{SiO}_{2}$ dari mother liquor sintesis zeolite $\mathrm{Y}$ dan turunannya, dengan penambahan bibit kristal lynde tipe Y 10\%-b dan senyawa mengandung alumina dalam starting material.

\section{Metode Penelitian}

\subsection{Karakterisasi mother liquor}

Karakterisasi mother liquor dilakukan dengan menggunakan alat Atomic Absorption Spectrophotometer (AAS) untuk mengetahui kandungan $\mathrm{SiO}_{2}$ dan $\mathrm{Al}_{2} \mathrm{O}_{3}$ diperlukan dalam penyusunan rasio molar $\mathrm{SiO}_{2} / \mathrm{Al}_{2} \mathrm{O}_{3}$ yang tertentu dalam starting material dengan melibatkan perhitungan kuantitas $\mathrm{SiO}_{2}$ dan $\mathrm{Al}_{2} \mathrm{O}_{3}$ dari bibit kristal yang ditambahkan.

\subsection{Pembuatan bibit kristal lynde type $\mathrm{Y}$}

Sintesis zeolite Y menggunakan bibit kristal lynde type $\mathrm{Y}$ yang memiliki komposisi molar $12,5 \mathrm{SiO}_{2}: \mathrm{Al}_{2} \mathrm{O}_{3}: 9,75 \mathrm{Na}_{2} \mathrm{O}: 485 \mathrm{H}_{2} \mathrm{O}$, dibuat dengan mengadopsi Ginter dkk. (1992). Natrium aluminat dan $\mathrm{NaOH}$ padat dilarutkan ke dalam air distilat sehingga homogen, kemudian ditambahkan larutan Na-silikat dan diaduk selama 30 menit untuk membentuk larutan bibit kristal. Selanjutnya, larutan bibit kristal dimatangkan selama 24 jam dan siap digunakan dalam sintesis zeolit Y.

\subsection{Preparasi starting material}

Sintesis zeolite Y dilakukan dengan menggunakan mother liquor dari sintesis zeolite Y sebelumnya. Bibit kristal yang berfungsi untuk mempercepat pembentukan kristal zeolite $\mathrm{Y}$, sekaligus juga memberikan penambahan $\mathrm{SiO}_{2}$ dan $\mathrm{Al}_{2} \mathrm{O}_{3}$ ke dalam mother liquor yang harus diperhitungkan dalam penyusunan komposisi starting material. Murat dkk. (1992) melaporkan bahwa untuk sintesis zeolite $\mathrm{Y}$ diperlukan rasio molar $\mathrm{SiO}_{2} / \mathrm{Al}_{2} \mathrm{O}_{3}$ di dalam starting material sekitar 7-10 mol/mol. Rendahnya kandungan $\mathrm{Al}_{2} \mathrm{O}_{3}$ di dalam mother liquor membuat penambahan sumber $\mathrm{Al}_{2} \mathrm{O}_{3}$ ke dalam mother liquor menjadi suatu kewajiban, untuk mendapatkan komposisi starting material sesuai dengan yang dikehendaki. Pada penelitian ini, sodium aluminat grade industri ditambahkan sebagai sumber $\mathrm{Al}_{2} \mathrm{O}_{3}$. Penyesuaian $\mathrm{pH}$ sekitar 13 pada starting material dilakukan melalui penambahan $\mathrm{NaOH}$ teknis di samping bibit kristal yang turut berkontribusi memberikan senyawa $\mathrm{Na}_{2} \mathrm{O}$.

\subsection{Sintesis zeolit $Y$}

Sintesis zeolite $\mathrm{Y}$ dilakukan secara hidrotermal pada temperatur $93^{\circ} \mathrm{C}$, di dalam reaktor Teflon berpengaduk berkapasitas $1 \mathrm{~L}$, kecepatan pengadukan $170 \mathrm{rpm}$. Reaktor harus bebas dari impuritas sebelum reaktor digunakan untuk sintesis zeolite Y (Thompson, 2000). Starting material yang telah dipersiapkan, dimatangkan pada temperatur ruang selama 11 jam sebelum dilakukan sintesis secara hidrotermal pada temperatur sekitar $93^{\circ} \mathrm{C}$ (Rahayu dkk., 2014), dengan variasi proses jenis mother liquor dan waktu sintesis. Produk zeolite Y dipisahkan dari mother liquor-nya melalui penyaringan dan pembilasan hingga $\mathrm{pH}$ sekitar 8. Selanjutnya mother liquor digunakan kembali sebagai sumber $\mathrm{SiO}_{2}$ untuk sintesis zeolite $\mathrm{Y}$ berikutnya. 


\subsection{Karakterisasi zeolit $Y$}

Karakterisasi produk zeolite $\mathrm{Y}$ dilakukan dengan menggunakan alat X-Ray Diffraction (XRD) untuk mengetahui nilai Unit Cel Size (UCS) dan rasio $\mathrm{SiO}_{2} / \mathrm{Al}_{2} \mathrm{O}_{3}$ zeolit $\mathrm{Y}$, dan alat Scanning Electron Microscopy (SEM) untuk melihat morfologi produk sintesis.

\section{Hasil dan Pembahasan}

\subsection{Kandungan $\mathrm{SiO}_{2}$ dan $\mathrm{Al}_{2} \mathrm{O}_{3}$ dalam mother liquor}

Hasil analysis mother liquor dari sintesis zeolite $\mathrm{Y}$ diperoleh kandungan $\mathrm{Al}_{2} \mathrm{O}_{3}$ yang jauh lebih rendah dari awalnya di dalam starting material. Hal ini disebabkan karena zeolit $\mathrm{Y}$ yang terbentuk memiliki rasio molar $\mathrm{SiO}_{2} / \mathrm{Al}_{2} \mathrm{O}_{3}$ yang jauh lebih rendah dari rasio yang terkandung di dalam starting material. Alumina di dalam starting material hampir semuanya terkonsumsi hingga menyisakan jumlah yang sangat rendah untuk pembentukan struktur zeolite $\mathrm{Y}$, seperti ditampilkan pada Tabel 1. Perbedaan kandungan $\mathrm{SiO}_{2}$ dan $\mathrm{Al}_{2} \mathrm{O}_{3}$ sangat besar di dalam setiap mother liquor. Oleh karena itu, sintesis zeolite $\mathrm{Y}$ menggunakan mother liquor akan memerlukan penambahan sejumlah $\mathrm{Al}_{2} \mathrm{O}_{3}$ untuk meningkatkan rasio molar $\mathrm{SiO}_{2} / \mathrm{Al}_{2} \mathrm{O}_{3}$ dalam starting material menjadi sekitar $10 \mathrm{~mol} / \mathrm{mol}$,. Hasil penelitian menunjukkan kandungan $\mathrm{SiO}_{2}$ yang tersisa dalam mother liquor turunan sekitar 40-50\%-b dari kandungan $\mathrm{SiO}_{2}$ dalam mother liquor sebelumnya, seperti tertera pada Tabel 1.

\subsection{Pengaruh starting material pada hasil sintesis zeolit Y}

Sintesis zeolite $\mathrm{Y}$ menggunakan mother liquor dari sintesis zeolite $\mathrm{Y}$ diawali dengan penyesuaian mother liquor untuk menjadi starting material yang memiliki rasio molar $\mathrm{SiO}_{2} / \mathrm{Al}_{2} \mathrm{O}_{3}$ sekitar $10 \mathrm{~mol} / \mathrm{mol}$ dan $\mathrm{pH}$ sekitar 13, melalui penambahan bibit kristal dan senyawa mengandung $\mathrm{Al}_{2} \mathrm{O}_{3}$. Tabel 2 menampilkan tiga tipe starting material yang digunakan dalam sintesis zeolite Y, yaitu starting material pertama dengan menggunakan Leached Metakaolin sebagai sumber $\mathrm{SiO}_{2}$, dan menghasilkan mother liquor turunan ke-1; starting material turunan ke-1 dengan sumber $\mathrm{SiO}_{2}$ dari mother liquor turunan ke-1, dan menghasilkan mother liquor turunan ke-2; starting material turunan ke-2 dengan sumber $\mathrm{SiO}_{2}$ mother liquor turunan ke-2, dan menghasilkan mother liquor turunan ke-3. Ketiga starting material memiliki rasio molar $\mathrm{SiO}_{2} / \mathrm{Al}_{2} \mathrm{O}_{3}$ sekitar $10 \mathrm{~mol} / \mathrm{mol}$, dengan kuantitas $\mathrm{SiO}_{2}$ menurun dari starting material I ke starting material turunan, karena terkonversi membentuk kristal zeolite $\mathrm{Y}$ dan tidak dilakukan penambahan $\mathrm{SiO}_{2}$ selain yang berasal dari bibit kristal.

Tabel 2 juga menampilkan formulasi starting material dan hasil sintesis zeolite $\mathrm{Y}$ yang dilakukan secara hidrotermal pada temperatur $93^{\circ} \mathrm{C}$, di dalam reaktor teflon berpengaduk berkapasitas $1 \mathrm{~L}$, kecepatan pengadukan $170 \mathrm{rpm}$, selama $15 \mathrm{jam}$. Tampak penaikan rasio molar $\mathrm{Na}_{2} \mathrm{O}$ pada starting material turunan sebagai dampak dari penambahan sodium aluminat sebagai sumber $\mathrm{Al}_{2} \mathrm{O}_{3}$ untuk penyesuaian rasio molar $\mathrm{SiO}_{2} / \mathrm{Al}_{2} \mathrm{O}_{3}$ di dalam starting material.

Perubahan komposisi dan konsentrasi $\mathrm{SiO}_{2}$ serta sifat fisik dan kimia yang terjadi pada mother liquor dari starting material-nya memberikan pengaruh pada hasil sintesis zeolite $\mathrm{NaY}$, apabila mother liquor digunakan sebagai sumber $\mathrm{SiO}_{2}$ untuk sintesis zeolite $\mathrm{Y}$, seperti ditampilkan pada Tabel 2. Secara kualitatif, capaian rasio molar $\mathrm{SiO}_{2} / \mathrm{Al}_{2} \mathrm{O}_{3}$ produk zeolite $\mathrm{Y}$ menurun secara linier dengan starting material turunan berikutnya. Perubahanperubahan yang terjadi diduga dapat memberikan penyimpangan lingkungan sistem reaksi meskipun ketentuan baku seperti rasio $\mathrm{SiO}_{2} / \mathrm{Al}_{2} \mathrm{O}_{3}$ dan $\mathrm{pH}$ starting material yang mendukung pembentukan zeolite $\mathrm{Y}$ telah sesuai. Perubahan sifat fisik dan kimia selama sintesis zeolite $\mathrm{Y}$ berlangsung mengindikasikan terbentuknya hasil konversi yang sebagian dapat bersifat tidak mendukung terbentuknya kristal zeolite Y. Kondisi ini sepadan dengan pernyataan Thompson (2000) bahwa impuritas dapat menurunkan reaktifitas $\mathrm{SiO}_{2}$ dan $\mathrm{Al}_{2} \mathrm{O}_{3}$ dalam sintesis zeolite Y. Thompson (2000) juga menyarankan untuk menggunakan reaktor yang bebas dari impuritas sebelum reaktor digunakan untuk sintesis zeolite Y, dan telah diacu dan diaplikasikan dalam penelitian ini melalui perendaman di dalam larutan $\mathrm{NaOH}$ encer. Sodium hidroksida juga merupakan salah satu senyawa yang diperlukan dalam sintesis zeolite $\mathrm{Y}$.

Gambar 1, Gambar 2, dan Gambar 3 memperlihatkan difraktogram hasil sintesis zeolite $\mathrm{Y}$ dari ketiga jenis starting material. Sintesis zeolite $\mathrm{NaY}$ dilakukan secara hidrotermal, menggunakan starting material I dengan leached metakaolin sebagai sumber $\mathrm{SiO}_{2}$. Leached metakaolin merupakan rafinat atau padatan kaya silika hasil leaching metakaolin, yang didesain memiliki rasio molar $\mathrm{SiO}_{2} / \mathrm{Al}_{2} \mathrm{O}_{3}=10 \mathrm{~mol} / \mathrm{mol}$ sebagai sumber $\mathrm{SiO}_{2}$ dengan penambahan bibit kristal Lynde tipe Y. Seperti telah diketahui bahwa bibit kristal di dalam sintesis zeolite $\mathrm{Y}$ selain berfungsi untuk mempercepat terbentuknya kristal zeolite juga berfungsi sebagai kontributor $\mathrm{SiO}_{2}$. Secara keseluruhan,tahap proses sintesis zeolite $\mathrm{Y}$ diawali oleh proses aging starting material dalam temperatur ruang selama 11 jam dan dilanjutkan proses hidrotermal pada temperatur sekitar $93^{\circ} \mathrm{C}$ selama $15 \mathrm{jam}$.

Tabel 1. Kandungan $\mathrm{SiO}_{2}$ dan $\mathrm{Al}_{2} \mathrm{O}_{3}$ dalam mother liquor sintesis zeolite $\mathrm{Y}$

\begin{tabular}{|c|c|c|c|}
\hline \multirow{2}{*}{ No. } & \multirow{2}{*}{ Mother Liquor } & \multicolumn{2}{|c|}{$\begin{array}{c}\text { Kandungan } \mathrm{SiO}_{2} \text { dan } \mathrm{Al}_{2} \mathrm{O}_{3} \\
\text { dalam mother liquor }\end{array}$} \\
\hline & & $\mathrm{SiO}_{2}(\mathrm{~g} / \mathrm{L})$ & $\mathrm{Al}_{2} \mathrm{O}_{3}(\mathrm{mg} / \mathrm{L})$ \\
\hline 1 & $\begin{array}{l}\text { Mother liquor } \\
\text { turunan ke-1 }\end{array}$ & 21.56 & 28.03 \\
\hline 2 & $\begin{array}{l}\text { Mother liquor } \\
\text { turunan ke-2 }\end{array}$ & 12.22 & 31.56 \\
\hline 3 & $\begin{array}{l}\text { Mother liquor } \\
\text { turunan ke-3 }\end{array}$ & 6.05 & 18.15 \\
\hline
\end{tabular}


Tabel 2. Hasil sintesis zeolite Y

\begin{tabular}{|c|c|c|c|}
\hline Sumber $\mathrm{SiO}_{2}$ & Starting Material & Formulasi Starting Material & $\begin{array}{c}\text { Rasio } \mathrm{SiO}_{2} / \mathrm{Al}_{2} \mathrm{O}_{3} \\
\text { zeolit } \mathrm{NaY} \\
(\mathrm{mol} / \mathrm{mol})\end{array}$ \\
\hline Leached Metakaolin & Starting material I & 2.6 $\mathrm{Na}_{2} \mathrm{O}: \mathrm{Al}_{2} \mathrm{O}_{3}: 9.9 \mathrm{SiO}_{2}: 341 \mathrm{H}_{2} \mathrm{O}$ & 3.47 \\
\hline $\begin{array}{c}\text { Mother liquor } \\
\text { turunan ke-1 }\end{array}$ & $\begin{array}{l}\text { Starting material } \\
\text { turunan ke-1 }\end{array}$ & 13.6 $\mathrm{Na}_{2} \mathrm{O}: \mathrm{Al}_{2} \mathrm{O}_{3}: 10.6 \mathrm{SiO}_{2}: 908 \mathrm{H}_{2} \mathrm{O}$ & 2.63 \\
\hline $\begin{array}{c}\text { Mother liquor } \\
\text { turunan ke-2 }\end{array}$ & $\begin{array}{l}\text { Starting material } \\
\text { turunan ke-2 }\end{array}$ & $31 \mathrm{Na}_{2} \mathrm{O}: \mathrm{Al}_{2} \mathrm{O}_{3}: 9.9 \mathrm{SiO}_{2}: 583 \mathrm{H}_{2} \mathrm{O}$ & 2.57 \\
\hline
\end{tabular}

Gambar 1 menampilkan difraktogram hasil sintesis zeolite $\mathrm{NaY}$ yang memiliki rasio $\mathrm{SiO}_{2} / \mathrm{Al}_{2} \mathrm{O}_{3}=3.47$ mol/mol disertai sedikit impuritas dari zeolite $\mathrm{P}$ dan kristal lainnya. Kerangka zeolite $\mathrm{Y}$ dengan rasio molar $\mathrm{SiO}_{2} / \mathrm{Al}_{2} \mathrm{O}_{3}=3.47 \mathrm{~mol} / \mathrm{mol}$ untuk zeolite $\mathrm{Y}$ tidak cukup kuat untuk dimodifikasi menjadi zeolite HY atau USY yang dapat digunakan sebagai katalis perengkahan, tetapi lebih sesuai untuk digunakan sebagai adsorben atau penukar ion.

Selanjutnya, mother liquor yang dihasilkan dari sintesis pertama yang kemudian disebut sebagai mother liquor turunan ke-1 digunakan kembali untuk sintesis zeolite Y berikutnya. Penyesuaian mother liquor turunan ke-1 untuk menjadi starting material turunan ke-1 yang memiliki rasio molar $\mathrm{SiO}_{2} / \mathrm{Al}_{2} \mathrm{O}_{3} 10 \mathrm{~mol} / \mathrm{mol}$ dan $\mathrm{pH}$ sekitar 13 dilakukan terlebih dahulu melalui penambahan bibit kristal lynde tipe Y sejumlah 10\%.b dalam starting material dan sodium aluminat sebagai sumber $\mathrm{Al}_{2} \mathrm{O}_{3}$ dan $\mathrm{Na}_{2} \mathrm{O}$.

Gambar 2 merupakan difraktogram zeolite $\mathrm{NaY}$ yang disintesis dengan menggunakan starting material turunan ke-1 dengan rasio molar $\mathrm{SiO}_{2} / \mathrm{Al}_{2} \mathrm{O}_{3}$ sekitar 10 mol/mol. Starting material menggunakan sumber $\mathrm{SiO}_{2}$ dari mother liquor I, dan bibit kristal lynde tipe Y $10 \%$ b. Hasil zeolite $\mathrm{NaY}$ yang diperoleh memiliki rasio molar $\mathrm{SiO}_{2} / \mathrm{Al}_{2} \mathrm{O}_{3}=2.63 \mathrm{~mol} / \mathrm{mol}$, lebih rendah secara signifikan dari rasio $\mathrm{SiO}_{2} / \mathrm{Al}_{2} \mathrm{O}_{3}$ pada zeolite $\mathrm{NaY}$ dengan starting material I dan sangat sedikit zeolite $\mathrm{P}$. Penyebab penurunan rasio $\mathrm{SiO}_{2} / \mathrm{Al}_{2} \mathrm{O}_{3}$ pada zeolite $\mathrm{Y}$ ini seperti telah diuraikan di atas, yaitu akibat reaktifitas $\mathrm{SiO}_{2}$ dan $\mathrm{Al}_{2} \mathrm{O}_{3}$ dalam starting material menurun. Gambar 3 merupakan mikrograf dari zeolite $\mathrm{NaY}$ yang dihasilkan dari starting material turunan ke-1.

Selanjutnya, mother liquor yang dihasilkan dari sintesis kedua, yang kemudian disebut sebagai mother liquor turunan ke-2 digunakan kembali untuk sintesis zeolite Y berikutnya. Penyesuaian mother liquor turunan ke-2 juga dilakukan untuk menjadi starting material turunan ke-2 yang memiliki rasio molar $\mathrm{SiO}_{2} / \mathrm{Al}_{2} \mathrm{O}_{3} 10$ $\mathrm{mol} / \mathrm{mol}$ dan $\mathrm{pH}$ sekitar 13 melalui penambahan bibit kristal lynde tipe $\mathrm{Y}$ sejumlah $10 \%$.b dalam starting material dan sodium aluminat sebagai sumber $\mathrm{Al}_{2} \mathrm{O}_{3}$ dan $\mathrm{Na}_{2} \mathrm{O}$. Penambahan $\mathrm{SiO}_{2}$ juga tidak dilakukan, kecuali yang berasal dari bibit kristal. Difraktogram hasil sintesis secara hidrotermal selama 15 jam ditampilkan pada Gambar 4. Difraktogram pada Gambar 4 menampilkan puncak kristal zeolite $\mathrm{X}$, zeolite $\mathrm{Y}$, dan zeolite $\mathrm{P}$ dengan intensitas yang hampir sama, dan zeolit $\mathrm{Y}$ yang terbentuk memiliki rasio molar $\mathrm{SiO}_{2} / \mathrm{Al}_{2} \mathrm{O}_{3}=2.57 \mathrm{~mol} / \mathrm{mol}$, sedikit lebih rendah dari sintesis menggunakan starting material turunan ke-1. Capaian ini menggambarkan kondisi lingkungan starting material yang semakin menurun dari starting material I sebagai parent starting material-nya, atau pun dari starting material turunan ke-1. Tampak juga fasa amorf yang lebih kuat dari difraktogram menggunakan starting material turunan ke-1, menunjukkan menurunnya kuantitas kristal yang terbentuk, bahkan terbentuk zeolite P secara signifikan. Keadaan ini memberikan gambaran, bahwa selektifitas reaksi ke arah pembentukan kristal zeolite $\mathrm{NaY}$ menurun secara linier dengan penurunan kualitas starting material yang digunakan dan penggunaan kembali mother liquor sintesis zeolite $\mathrm{Y}$ tampak layak dilakukan terbatas pada mother liquor turunan ke-1 saja. Terbentuknya zeolite $\mathrm{P}$ patut untuk diperhatikan karena zeolite $\mathrm{P}$ juga terbentuk oleh nutrien yang sama dengan nutrient pembentuk $\mathrm{NaY}$, sehingga dapat menurunkan kemurnian zeolite $\mathrm{Y}$ di dalam kristal hasil sintesisn di mana keduanya tidak dapat dipisahkan. Kedua zeolite memiliki fungsi berbeda, fungsi zeolite Y sebagai perengkah hidrokarbon dan fungsi zeolite $\mathrm{P}$ sebagai adsorben atau penukar ion, membuat penurunan kristal zeolite $\mathrm{Y}$ akibat terbentuknya kristal zeolite $\mathrm{P}$ akan merugikan. 
Penggunaan Kembali Limbah Cair dari Sintesis Zeolit Y sebagai Sumber Silika untuk Sintesis Zeolit Y secara Hidrotermal

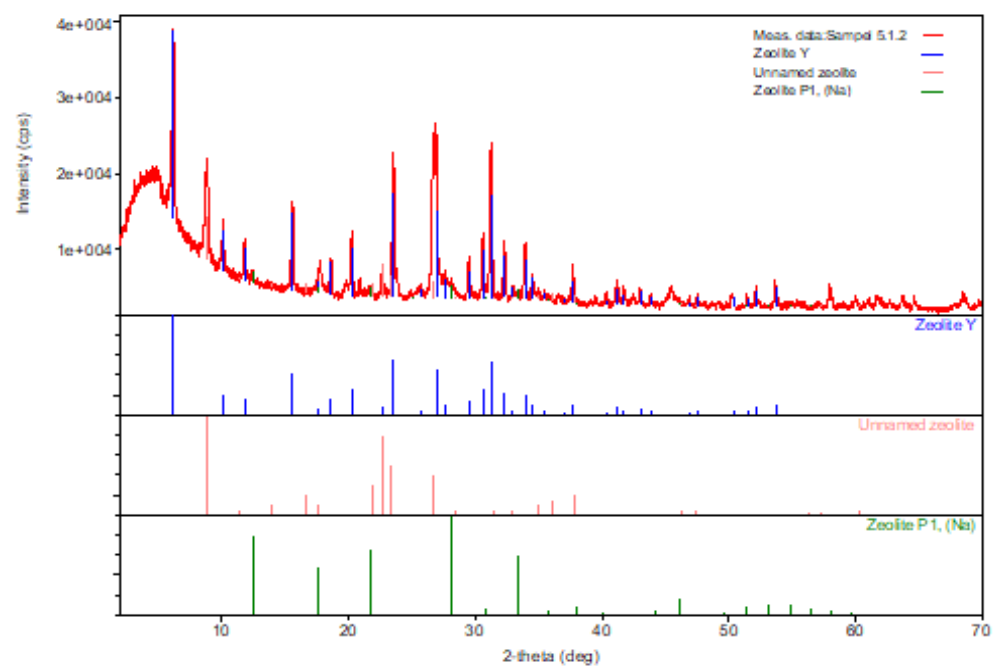

Gambar 1. Difraktogram zeolit NaY, dengan starting material mengandung leached metakaolin 2.6 $\mathrm{Na}_{2} \mathrm{O}: \mathrm{Al}_{2} \mathrm{O}_{3}: 9.9 \mathrm{SiO}_{2}: 341 \mathrm{H}_{2} \mathrm{O}$, waktu reaksi $15 \mathrm{jam}$

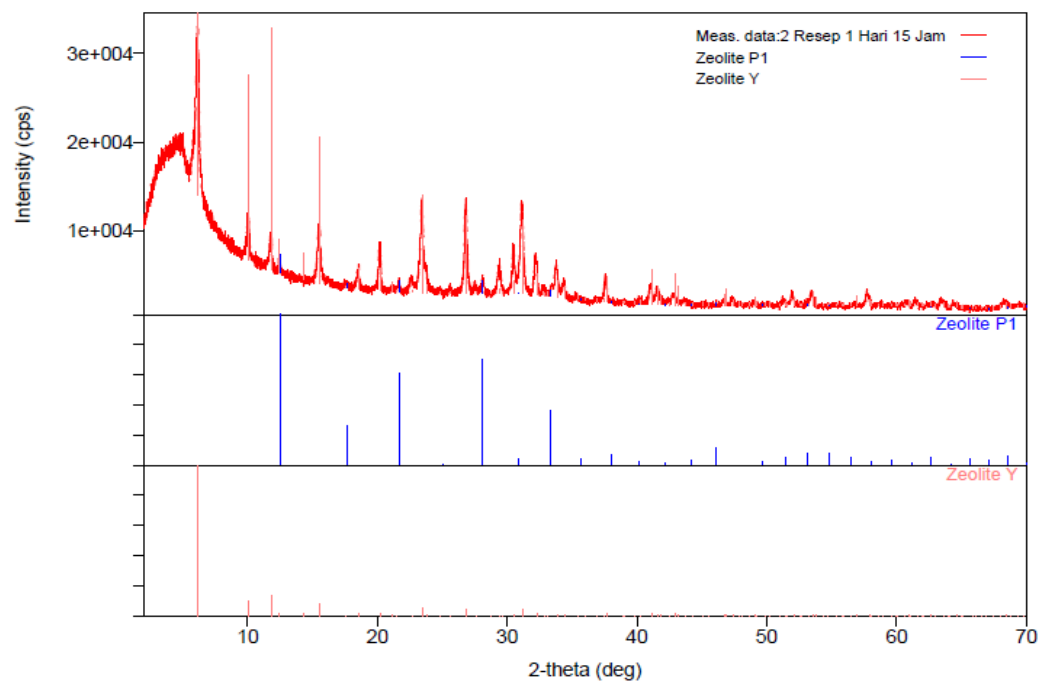

Gambar 2. Difraktogram zeolit $\mathrm{NaY}$ dengan starting material turunan ke-1, $13.6 \mathrm{Na}_{2} \mathrm{O}: \mathrm{Al}_{2} \mathrm{O}_{3}: 10.6 \mathrm{SiO}_{2}: 908 \mathrm{H}_{2} \mathrm{O}$, waktu $15 \mathrm{jam}$

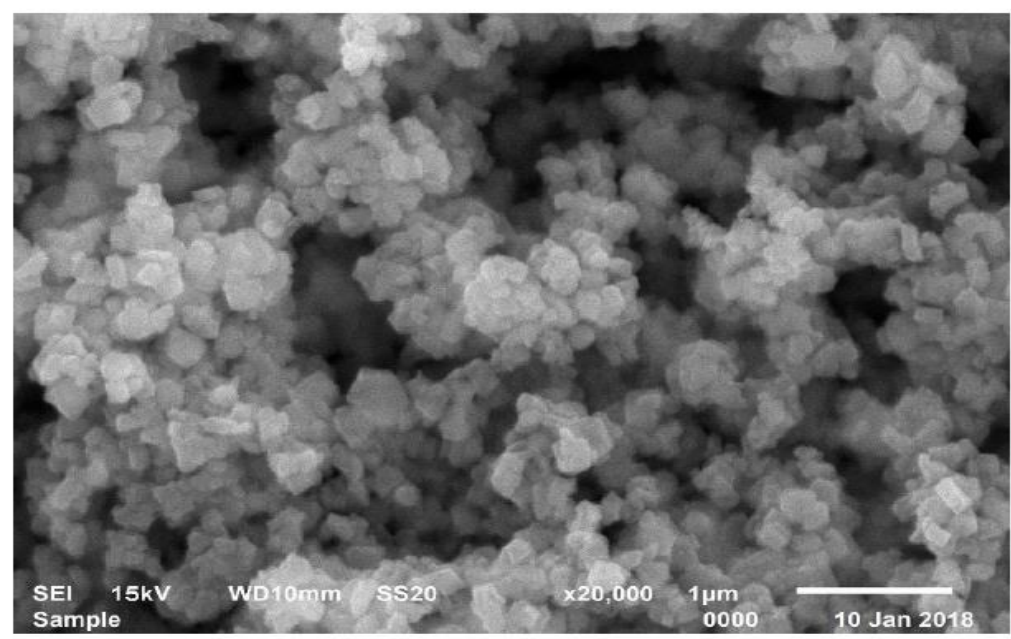

Gambar 3. Mikrograf zeolit NaY perbesaran 20000X dengan starting material turunan ke-1, 13.6 $\mathrm{Na}_{2} \mathrm{O}: \mathrm{Al}_{2} \mathrm{O}_{3}: 10.6 \mathrm{SiO}_{2}: 908 \mathrm{H}_{2} \mathrm{O}$, waktu sintesis $15 \mathrm{jam}$ 


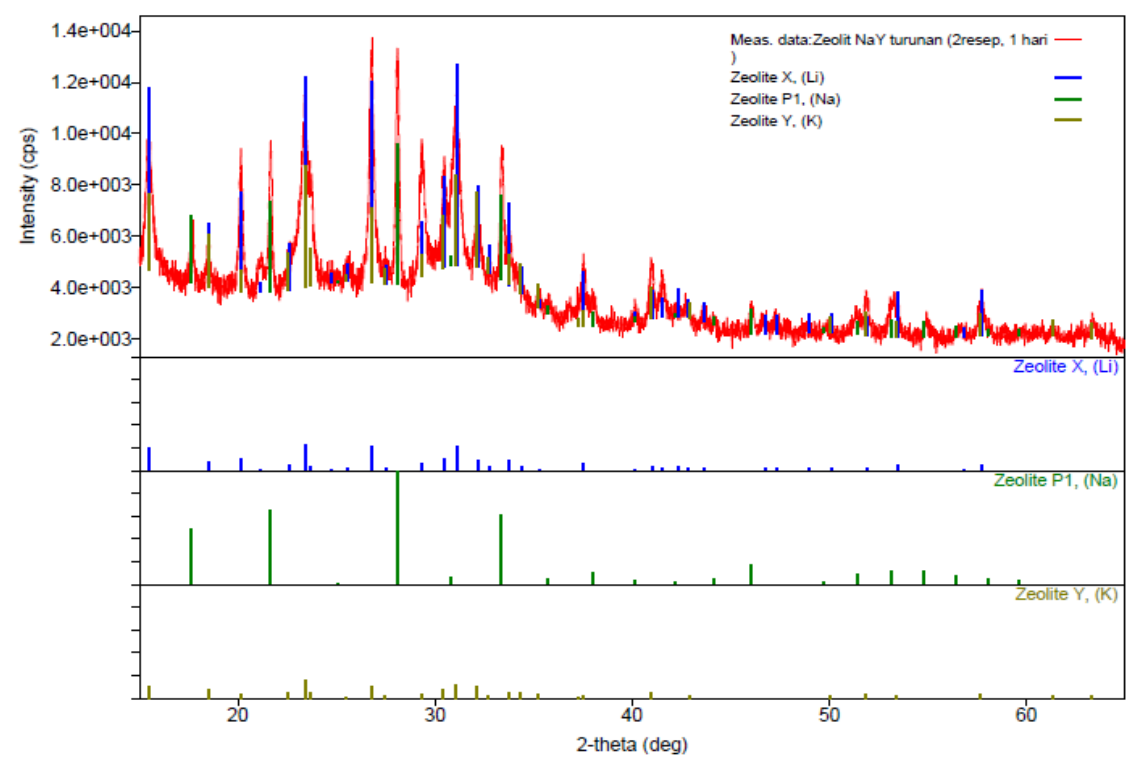

Gambar 4. Difraktogram zeolit $\mathrm{NaY}$ dengan starting material turunan ke-2, $31 \mathrm{Na}_{2} \mathrm{O}: \mathrm{Al}_{2} \mathrm{O}_{3}: 9.9 \mathrm{SiO}_{2}: 583 \mathrm{H}_{2} \mathrm{O}$, waktu sintesis 15 jam

\subsection{Pengaruh waktu sintesis pada hasil sintesis} zeolit Y

Sintesis NaY menggunakan mother liquor sebagai sumber $\mathrm{SiO}_{2}$ memiliki fasa homogen memberikan karakter proses yang berbeda dengan sintesis fasa heterogen, seperti ditampilkan pada Gambar 5, yang tampak telah terbentuk zeolite $\mathrm{NaY}$ secara cepat dalam waktu sintesis selama 8 jam, pada sintesis zeolit NaY menggunakan starting material turunan ke-1. Terbentuknya zeolite $\mathrm{NaY}$ ini relatif lebih cepat dari sintesis zeolite $\mathrm{Y}$ dengan bahan padat leached metakaolin sebagai sumber $\mathrm{SiO}_{2}$ (Rahayu dkk., 2018) yang memerlukan waktu 15 jam. Zeolit NaY terbentuk dengan intensitas yang cukup kuat pada difraktogram hanya dalam waktu sintesis sekitar 8 jam. Hasil zeolite $\mathrm{NaY}$ dengan bahan limbah cair ini memiliki rasio molar $\mathrm{SiO}_{2} / \mathrm{Al}_{2} \mathrm{O}_{3}=2.61 \mathrm{~mol} / \mathrm{mol}$, lebih rendah dari yang dicapai parent starting material-nya yaitu:3.47 $\mathrm{mol} / \mathrm{mol}$.

Zeolite NaY terbentuk dalam waktu sintesis 8 jam karena kecepatan reaksi pembentukan kristal zeolite $\mathrm{NaY}$ lebih tinggi dalam fasa homogen, walaupun konsentrasi $\mathrm{SiO}_{2}$ lebih rendah dari $\mathrm{SiO}_{2}$ yang terkandung di dalam parent starting material. Kecepatan reaksi pembentukan kristal zeolite Y tinggi didukung oleh lingkungan sistem reaksi yang sesuai dan fasa homogen. Fasa homogen sistem reaksi akan memberikan waktu induksi untuk kristalisasi yang cepat, karena tidak memerlukan pelarutan fasa padat, seperti pada fasa heterogen padat-cair parent starting material yang menggunakan leached metakaolin sebagai sumber $\mathrm{SiO}_{2}$. Fasa homogen pada sintesis zeolite $\mathrm{Y}$ yang memanfaatkan mother liquor sebagai sumber $\mathrm{SiO}_{2}$ tampak memberikan penghematan waktu proses, merupakan bentuk keuntungan yang lain di samping pemanfaatan sisa $\mathrm{SiO}_{2}$ di dalam limbah cair.

Telah diketahui bahwa waktu akan memberikan pengaruh terhadap terbentuknya zeolite P. Sintesis zeolite $\mathrm{Y}$ dengan menggunakan mother liquor turunan ke-1 ini telah membentuk sedikit zeolite $\mathrm{P}$ pada waktu sintesis berlangsung selama 8 jam. Kecenderungan mulai terbentuknya zeolite $\mathrm{P}$ banyak ditemui setelah proses melampaui 15 jam (Murrat dkk., 1992; Rahayu dkk., 2014). Zeolit P dapat terbentuk melalui reaksi paralel bersamaan dengan terbentuknya zeolite $\mathrm{NaY}$, dan/atau reaksi seri dari zeolite Y yang telah terbentuk, kemudian terkonversi membentuk zeolit P. Seiring terbentuknya zeolite $\mathrm{P}$, penaikan waktu sintesis hingga 21 jam, juga akan memberikan penaikan rasio $\mathrm{SiO}_{2} / \mathrm{Al}_{2} \mathrm{O}_{3}$ pada zeolite $\mathrm{NaY}$, yaitu $2.73 \mathrm{~mol} / \mathrm{mol}$, seperti ditampilkan pada Tabel 2.

\subsection{Pengaruh bibit kristal pada pembentukan zeolit P \\ Bibit kristal berpengaruh terhadap capaian rasio} $\mathrm{SiO}_{2} / \mathrm{Al}_{2} \mathrm{O}_{3}$ pada hasil zeolit $\mathrm{Y}$. Peranan bibit kristal yang berfungsi untuk meningkatkan laju kristalisasi dan memberikan selektifitas pembentukan zeolite yang dikehendaki, telah ditunjukkan pada peningkatan capaian rasio $\mathrm{SiO}_{2} / \mathrm{Al}_{2} \mathrm{O}_{3}$ dan pembentukan zeolite $\mathrm{P}$, ketika jumlah bibit kristal ditingkatkan dari 5\%-b menjadi $7.5 \%$-b dan $10 \%$-b. Besar pengaruh bibit kristal dapat diduga mendekati linier terhadap konsentrasi bibit kristal dalam starting material. Namun dalam penelitian ini, bibit kristal dibatasi tidak lebih dari $10 \%$-b dalam starting material, untuk lebih menekankan penggunaan $\mathrm{SiO}_{2}$ dari mother liquor. 


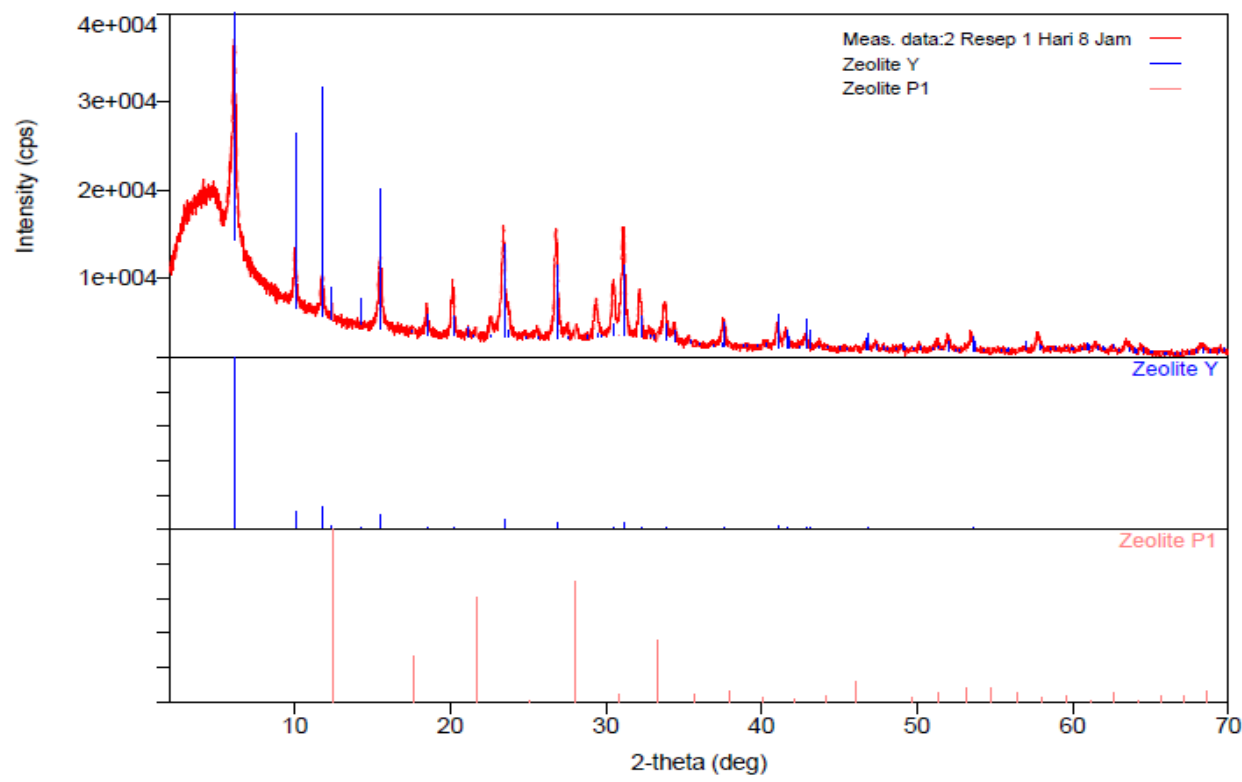

Gambar 5. Difraktogram zeolite $\mathrm{NaY}$ dari mother liquor turunan ke-1, $13.6 \mathrm{Na}_{2} \mathrm{O}: \mathrm{Al}_{2} \mathrm{O}_{3}: 10.6 \mathrm{SiO}_{2}: 908 \mathrm{H}_{2} \mathrm{O}$, waktu sintesis 8 jam

Tabel 2. Pengaruh waktu reaksi dan jumlah bibit kristal terhadap capaian kualitas zeolite NaY

\begin{tabular}{|c|c|c|c|c|}
\hline \multicolumn{2}{|c|}{ Bibit Kristal } & \multirow{2}{*}{$\begin{array}{l}\text { Waktu Sintesis } \\
\text { (Jam) }\end{array}$} & \multirow{2}{*}{$\begin{array}{c}\text { Zeolit Y } \\
\text { Rasio } \mathrm{SiO}_{2} / \mathrm{Al}_{2} \mathrm{O}_{3} \\
(\mathrm{~mol} / \mathrm{mol})\end{array}$} & \multirow[b]{2}{*}{ Zeolit P } \\
\hline $\begin{array}{l}\text { Jumlah } \\
(\%-b)\end{array}$ & $\begin{array}{c}\text { Waktu Aging } \\
\text { (Jam) }\end{array}$ & & & \\
\hline 10 & 24 & 8 & 2.61 & $\mathrm{~V}$ \\
\hline 10 & 24 & 11 & 2.61 & $\mathrm{v}$ \\
\hline 10 & 24 & 15 & 2.63 & vv \\
\hline 10 & 24 & 19 & 2.71 & VvV \\
\hline 10 & 24 & 21 & 2.73 & vVv \\
\hline 5 & 24 & 15 & 2.53 & vVv \\
\hline 7.5 & 24 & 15 & 2.56 & vVv \\
\hline 10 & 24 & 15 & 2.63 & VV \\
\hline
\end{tabular}

Keterangan: v = sedikit; vv = lebih banyak; vvv = banyak.

Produk sintesis zeolite NaY menggunakan mother liquor atau limbah cair dari sintesis zeolite sebelumnya, menghasilkan zeolite $\mathrm{NaY}$ dengan rasio molar $\mathrm{SiO}_{2} / \mathrm{Al}_{2} \mathrm{O}_{3}$ rendah. Produk ini tidak dapat digunakan untuk katalis perengkahan karena kurang cukup stabil untuk dimodifikasi membentuk zeolite HY atau USY. Penggunaan zeolit $\mathrm{NaY}$ rendah $\mathrm{SiO}_{2} / \mathrm{Al}_{2} \mathrm{O}_{3}$ sebagai adsorben ataupun sebagai penukar kation telah dilaporkan oleh para peneliti sebelumnya seperti Rongchapo dkk. (2018) dan Li dkk. (2015).

\section{Kesimpulan}

Mother liquor dari sintesis zeolite $\mathrm{NaY}$, dapat digunakan kembali sebagai sumber $\mathrm{SiO}_{2}$ untuk sintesis zeolite Y melalui penyesuaian komposisi dalam starting material. Hasil sintesis zeolite $\mathrm{Y}$ menunjukkan hanya mother liquor turunan ke-1 saja yang layak digunakan kembali untuk sintesis zeolite $\mathrm{Y}$ karena zeolite $\mathrm{P}$ terbentuk secara signifikan ketika digunakan mother liquor turunan ke-2. Pembentukan zeolite $\mathrm{P}$ terjadi karena konsentrasi $\mathrm{SiO}_{2}$ yang rendah dalam starting material, merupakan tambahan pernyataan yang telah ada sebelumnya, bahwa dalam sintesis zeolite $\mathrm{Y}$ akan terbentuk zeolite $\mathrm{P}$ apabila temperatur dinaikkan hingga di atas $100^{\circ} \mathrm{C}$ atau waktu reaksi dinaikkan hingga di atas 25 jam. Zeolit $\mathrm{NaY}$ terbentuk dalam penelitian ini juga lebih cepat ( 8 jam) dari sintesis zeolite $Y$ yang menggunakan leached metakaolin sebagai sumber $\mathrm{SiO}_{2}$ dalam parent starting material (11 jam), disebabkan oleh fasa homogen dalam sistem reaksi yang menggunakan mother liquor sebagai sumber $\mathrm{SiO}_{2}$. Data lain yang diperoleh dalam penelitian ini adalah bahwa konsentrasi $\mathrm{SiO}_{2}$ yang rendah dalam mother liquor turunan akan menurunkan rasio $\mathrm{SiO}_{2} / \mathrm{Al}_{2} \mathrm{O}_{3}$ pada zeolit $\mathrm{Y}$ hasil sintesis. Peningkatan rasio $\mathrm{SiO}_{2} / \mathrm{Al}_{2} \mathrm{O}_{3}$ zeolit $\mathrm{Y}$ hasil sintesis tampak lebih baik dilakukan melalui penaikan jumlah bibit kristal dari pada melalui penaikan waktu reaksi untuk memperkecil terbentuknya zeolite $\mathrm{P}$. 


\section{Ucapan Terima Kasih}

Kami mengucapkan terima kasih kepada DRPM Ditjen Penguatan Riset dan Pengembangan KeMenRistekDikti yang telah memfasilitasi pendanaan penelitian ini melalui Skema Penelitian Produk Terapan 2017.

\section{Daftar Pustaka}

Adeoye, J.B.; Omoleye, J.A., Development of Zeolit Y from Arobieye Mined Kaolin. $3^{\text {rd }}$ International Conference on African Development Issues (CU-ICADI) 2016, Ota, May 9-11, 2016.

Brown, S.M.; Woltermann, G.M., Zeolitized Composite Bodies and Manufacture Thereof. US Patent 4,235,753, 1980.

Ginter, D.M.; Bell, A.T.; Radke, C.J., Synthesis of Microporous Materials, Molecular Sieves. New York: Van Nostrand Reinhold, 1992.

Li, Q.; Zhang, Y.; Cao, Z.; Gao, W.; Cui, L., Influence of Synthesis Parameters on the Crystallinity and $\mathrm{Si} / \mathrm{Al}$ ratio of NaY Zeolite Synthesized from Kaolin. Petroleum Science, 2010, 7, 403-409.

Li, X.; Narayanan, S.; Michaelis, V.K.; Ong, T.C-.; Keeler, E.G.; Kim, H.; McKay, I.S.; Griffin, R.G.; Wang, E.N., Zeolite Y Adsorbents with High Vapor Uptake Capacity and Robust Cycling Stability for Potential Applications in Advanced Adsorption Heat Pumps. Microporous and Mesoporous Materials, 2015, 201, 151-159.
Murat, M.; Amokrane, A.; Bastide, J.P.; Montanaro, L., Synthesis of Zeolites from Thermally Activated Kaolinite. Some Observation on Nucleation and Growth. Clay Minerals, 1992, 27, 119-130.

Rahayu, E.S.; Subagjo; Samadhi, T.W.; Laniwati, M.G., Development of Hydrocracking Catalyst Support from Kaolin of Indonesian Origin. Advanced Materials Research, 2014, 896, 532-536.

Rahayu, E.S.; Subiyanto, G.; Imanuddin, A.; Wiranto; Nadina; Ristiani, S.R.; Suhermina; Yuniarti, E., Kaolin as a Source of Silica and Alumina for Synthesis of Zeolite Y and Amorphous Silica Alumina. MATEC Web of Conferences, 2018, 156, 05002.

Rongchapo, W.; Keawkumay, C.; Osakoo, N.; Deekamwong, K.; Chanlek, N.; Prayoonpokarach, S.; Wittayakun, J., Comprehension of Paraquat Adsorption on Faujasite Zeolite $\mathrm{X}$ and $\mathrm{Y}$ in Sodium Form. Adsorption Science \& Technology, 2018, 36(1-2), 684693.

Thompson, R.W., Nucleation, Growth and Seeding in Zeolite Synthesis. Robson, H.; Lillerud, K.P., eds. Verified Syntheses of Zeolitic Materials. London: Elsevier, 2001, pp. 21-23. 